\title{
LUPUS SCIENCE\& MEDICINE \\ Very delayed lupus nephritis: a report of three cases and literature review
}

\author{
André R Alexandre, ${ }^{1}$ Pedro L Carreira, ${ }^{2}$ David A Isenberg ${ }^{3}$
}

To cite: Alexandre AR, Carreira PL, Isenberg DA. Very delayed lupus nephritis: a report of three cases and literature review. Lupus Science \& Medicine 2018;5:e000241. doi:10.1136/ lupus-2017-000241

ARA and PLC contributed equally.

Received 20 September 2017 Revised 23 November 2017 Accepted 27 November 2017

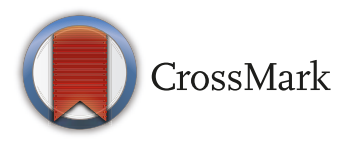

${ }^{1}$ Department of Internal and Intensive Medicine, Hospital da Luz, Lisboa, Portugal

${ }^{2}$ Autoimmune Diseases Unit, Internal Medicine 7.2 Department, Hospital Curry Cabral, Centro Hospitalar Lisboa Central, Lisbon, Portugal

${ }^{3}$ Centre for Rheumatology, University College London, London, UK

Correspondence to Dr David A Isenberg; D. Isenberg@ucl.ac.uk

\section{ABSTRACT}

Lupus nephritis (LN) affects up to $50 \%$ of patients with Systemic Lupus Erythematosus (SLE) and is associated with a worse prognosis. LN usually develops within the first 5 years of the onset of the disease. We report three patients with very delayed LN (DLN) diagnosed after 15 or more years after SLE diagnosis. The three patients were non-Caucasian women with adolescent or adult-onset SLE. Each had antinuclear, anti-dsDNA and anti-Ro antibodies. Hydroxychloroquine was prescribed for each. Their disease courses were characterised by sporadic non-renal flares controlled by steroids and, in two cases, by one cycle of rituximab. Unexpectedly, they developed proteinuria, haematuria and lowering of estimated glomerular filtration rate with clinical signs of renal disease. LN was confirmed by renal biopsy. Reviewing them, each showed serological signs of increasing disease activity (rising levels of antidsDNA antibodies and fall in C3) that predated clinical or laboratory signs of LN by 1-3years. Reviewing the literature, we found a lack of knowledge about DLN starting more than 15 years after SLE diagnosis. With the increasing life expectancy of patients with SLE it is likely that more cases of very DLN will emerge.

\section{INTRODUCTION}

Clinically evident lupus nephritis (LN) is a frequent form of organ involvement in up to $50 \%$ of patients with SLE and carries a worse prognosis than non-renal disease. ${ }^{12}$ As reported recently from our own SLE cohort, $34.6 \%$ of 673 patients followed up between 1978 and 2015 developed overt renal disease (biopsy proven in $90 \%$ ). ${ }^{3}$

The vast majority of patients who develop LN do so within 5 years of SLE diagnosis, few do so subsequently $(5 \%-15 \%) .{ }^{14}$ Delayed LN (DLN) may carry a worse prognosis than LN presenting sooner, ${ }^{5}$ although the data are conflicting. ${ }^{4}{ }^{6}$ DLN can affect any age and must be differentiated from late-onset LN (LLN), a form of LN occurring in patients diagnosed with SLE after 50 years of age. LLN seems to have a slightly better renal outcome when compared with early-onset LN. ${ }^{7}$

Although a very small percentage of our patients have developed their renal disease after 7 years of SLE diagnosis ${ }^{2}$ interestingly, and unexpectedly, in the past few years three patients have developed biopsy-proven LN
15 years or more (figure 1 ) after meeting the revised American College of Rheumatology criteria for the classification of SLE. ${ }^{8}$ We now report these three unusual cases trying to identify any abnormal features they might share and reviewed the literature about very DLN.

\section{CASE REPORTS}

\section{Case 1}

A 28-year-old African woman first presented to our clinic with a malar rash, polyarthritis, serositis and Coombs positive haemolytic anaemia. She had a high ANA titre $(>1: 320)$ with a diffuse pattern and anti-Ro and antidsDNA antibodies. Antibodies to other extractable nuclear antigens and phospholipids were all negative. Her C3 complement level was low $(0.69 \mathrm{~g} / \mathrm{L}(\mathrm{NR}=0.9-1.8))$. This presentation led to her SLE diagnosis, and treatment was initiated with steroids and hydroxychloroquine. Her disease was kept under control for 9 years apart from intermittent mild tiredness and arthralgia. Secondary Sjögren syndrome (SS) was also diagnosed.

From the ninth year after SLE diagnosis onwards, she began to have multiple episodes of arthritis flares requiring a maintenance dose of oral steroids. At age 41, she had a first trimester miscarriage without changes in her antiphospholipid antibody profile.

During her 16th year of disease she had a serious episode of pleurisy and myocarditis requiring hospitalisation for intravenous steroid therapy. Subsequently, she was started on rituximab. She had to be hospitalised again 1 year later due to Escherichia coli renal abscesses. Rituximab was stopped and she was switched to mycophenolate mofetil (MMF) and then to azathioprine after her recovery. She developed hypertension during the following year and was started on amlodipine and ramipril.

During the 19th year of her disease, age 47 , she began to experience increasing tiredness with peripheral oedema and worsening hypertension. Her urinary tests showed de 


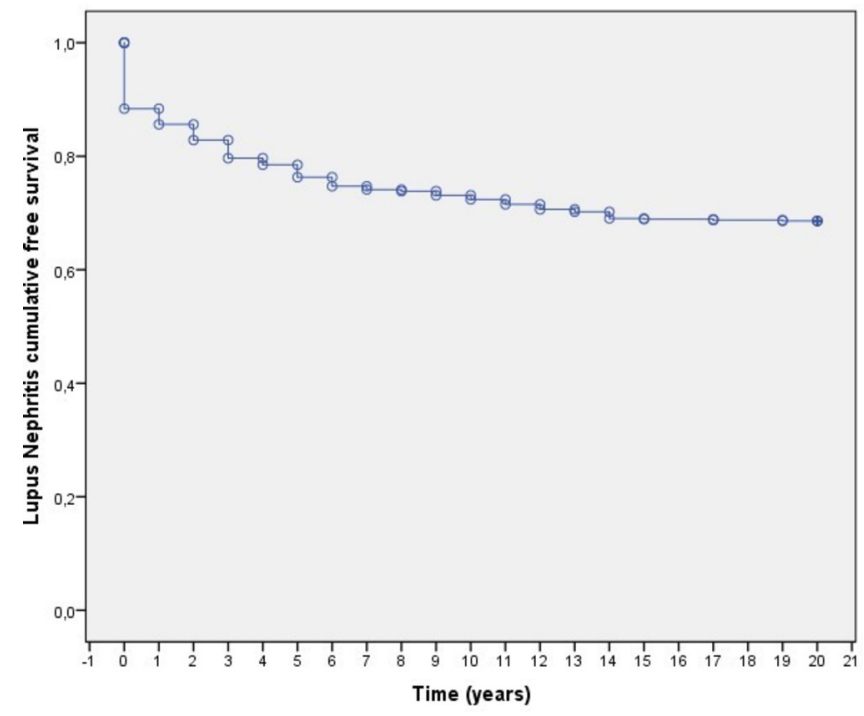

Figure 1 Lupus nephritis cumulative free survival time in years of our SLE cohort.

novo haematuria and proteinuria with a urinary protein/ creatinine ratio (UPCR) of $438 \mathrm{mg} / \mathrm{mmol}(\mathrm{NR}<15)$. Her estimated glomerular filtration rate (eGFR) (by Modification of Diet in Renal Disease study equation) fell to $30 \mathrm{~mL} / \mathrm{min} / 1.73 \mathrm{~m}^{2}$ (previously $>90 \mathrm{~mL} / \mathrm{min} / 1.73 \mathrm{~m}^{2}$ ) in 3 months. A kidney biopsy showed a class IV LN (WHO classification) with very active diffuse proliferative changes.

Her C3 level had always been low reaching a nadir 2 years before the LN diagnosis, recovering with the introduction of azathioprine, but slowly falling $(0.49 \mathrm{~g} / \mathrm{L})$ for about a year until the renal biopsy. In contrast, her antidsDNA antibody levels were normal until her 15th year of disease when they started to rise predating the pleurisy and myocarditis flare. They fluctuated subsequently never returning to normal. During the year before the renal biopsy they rose steeply to a maximum (3171 IU/ $\mathrm{mL}(\mathrm{NR}<50))$. Both markers returned to normal after the $\mathrm{LN}$ treatment (figure 2).

She was treated with $2 \mathrm{~g}$ /day of MMF and $1 \mathrm{mg} / \mathrm{kg}$ of prednisolone followed by a decreasing dose of steroids achieving a complete remission (proteinuria $\leq 0.33 \mathrm{~g} /$ day and serum creatinine $\leq 1.4 \mathrm{mg} / \mathrm{dL}$ ) in 6 months' time. Hydroxychloroquine was maintained during her entire illness.

The patient experienced a LN flare a year after induction treatment $(\mathrm{UPCR}=127 \mathrm{mg} / \mathrm{mmol})$. Increasing the dose of MMF to $2.5 \mathrm{~g} /$ day led to a partial remission ( $50 \%$ reduction in baseline proteinuria to $\leq 1.5 \mathrm{~g}$ /day and $\leq 25 \%$ increase in baseline creatinine) and chronic kidney disease.

She is now in her 24th year of disease, without apparent SLE activity, controlled with MMF $1.5 \mathrm{~g} /$ day, prednisolone $5 \mathrm{mg}$ /day and hydroxychloroquine $400 \mathrm{mg}$ /day.

\section{Case 2}

A 15-year-old Indian woman was diagnosed with SLE after she presented with an inflammatory polyarthritis,
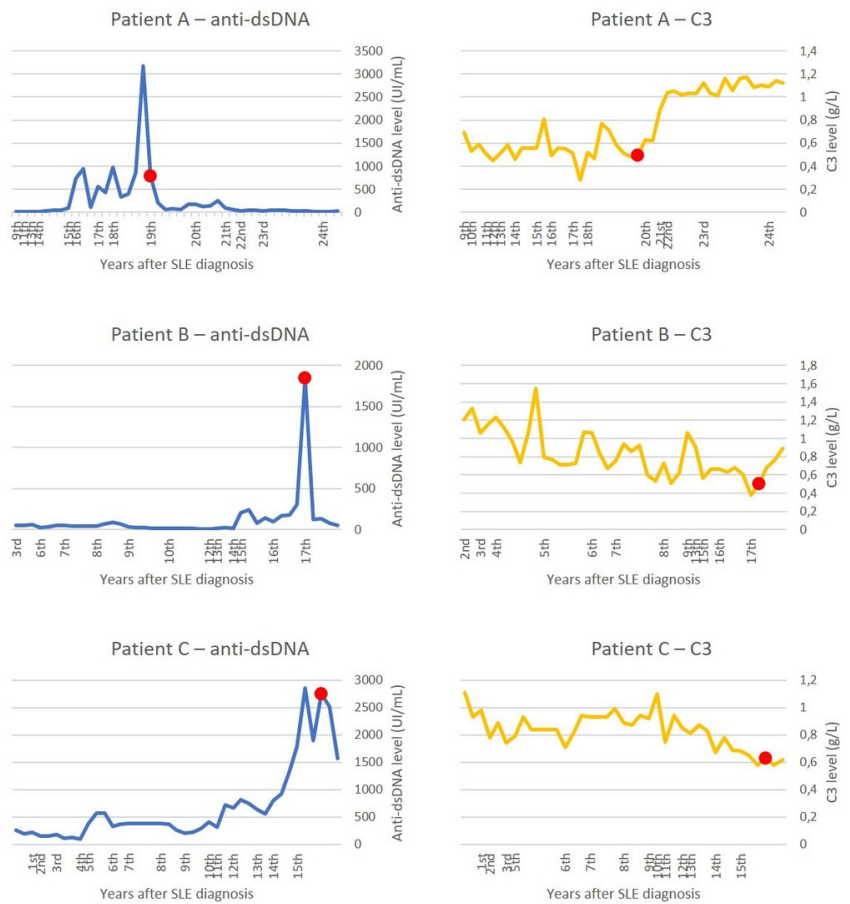

Figure 2 Anti-dsDNA antibodies and C3 level profile during SLE course of the three patients. Red markers indicate the moment of kidney biopsy.

headaches, fatigue, malar rash and alopecia. She had a positive ANA ( $>1: 320)$, anti-Ro and anti-dsDNA antibodies with normal C3 levels. She was treated with hydroxychloroquine and afterwards with azathioprine and prednisolone for a period of 2 years. Subsequently, she was maintained only on hydroxychloroquine.

Seven years after diagnosis she developed a flare consisting of vasculitis of her fingers and toes, arthritis, facial rash and alopecia, dyspnoea and mouth ulcers. Steroid therapy was not effective and she was treated with one cycle of cyclophosphamide and two infusions of rituximab to achieve disease control. She had subsequent mild flares of arthritis and vasculitis well controlled with steroids despite shingles and chest infections.

Immunologically, she usually had a normal anti-dsDNA antibody level, a low C3 level and mainly normal values of erythrocyte sedimentation rate (ESR) and C-reactive protein (CRP). In the last 2 years, her anti-dsDNA antibody levels increased with worsening low C3, despite being asymptomatic.

After 17 years of SLE, age 32, she developed proteinuria for the first time with a UPCR of $148 \mathrm{mg} / \mathrm{mmol}$. Her inflammatory markers were low, C3 and anti-dsDNA levels stable. A urine sample was repeated to confirm the proteinuria which was negative.

About 5 months after, she had another flare with dyspnoea, arthritis, malar rash and mouth ulcers. She was again found to have proteinuria, this time with mild hypertension and oedema. The UPCR was now $986 \mathrm{mg} /$ mmol and the eGFR fell to $69 \mathrm{~mL} / \mathrm{min} / 1.73 \mathrm{~m}^{2}$. Inflammatory markers were only slightly elevated $(\mathrm{ESR}=28 \mathrm{~mm} /$ hour; $\mathrm{CRP}=3.6 \mathrm{mg} / \mathrm{L}$ ) but there was evidence of 
SLE serological activity (anti-dsDNA $=1847 \mathrm{IU} / \mathrm{mL}$; C3 $=0.38 \mathrm{~g} / \mathrm{L}$ ). She underwent a kidney biopsy which confirmed the LN diagnosis consistent with WHO active class IV+V with patchy background parenchymal oedema without chronic damage. She was started on MMF $2 \mathrm{~g} /$ day with prednisolone $1 \mathrm{mg} / \mathrm{kg}$ (followed by a decreasing dose until reaching $20 \mathrm{mg} /$ day) and hydroxychloroquine $400 \mathrm{mg}$ /day. Later, two infusions of rituximab (1 g each) were given due to incomplete response. She is currently stable in complete remission. Her levels of anti-dsDNA and C3 normalised.

\section{Case 3}

A 32-year-old Asian woman was diagnosed with SLE after she developed an inflammatory polyarthritis and fatigue. Serologically, she had ANA, anti-dsDNA and anti-Ro antibodies positive with normal C3 levels but with leucopenia. She was treated with hydroxychloroquine $400 \mathrm{mg}$ /day.

Three years after the diagnosis, she had a flare characterised by discoid lupus on her neck and arthritis in hands and knees. It was controlled with intramuscular prednisolone. During the disease course, she had occasional arthritis flares well controlled with steroids. She also had an episode of Raynaud's phenomena and alopecia.

During the 12th year of disease, she had three bouts of pneumonia. During the investigation, pulmonary cysts and calcified nodules were found. No cause for them was found.

Immunologically, she usually had raised anti-dsDNA antibodies and low C3 levels (figure 2) but with normal values of ESR and CRP. In the last 3 years, her anti-dsDNA antibody levels increased with an additional fall in C3 levels without clinical signs or symptoms.

Finally, after 15 years of SLE, age 47, she presented with worsening arthritis that responded adequately to rapidly tapering steroids cycle. Her anti-dsDNA antibodies and C3 levels were little changed and no proteinuria was found. However, 2 months later she got a viral infection, the arthritis returned (steroids were started again) and for the first time she had proteinuria and haematuria. Her UPCR was $273 \mathrm{mg} / \mathrm{mmol}$ and the eGFR fell to $59 \mathrm{~mL} / \mathrm{min} / 1.73 \mathrm{~m}^{2}$. Inflammatory markers were elevated $\quad(\mathrm{ESR}=20 \mathrm{~mm} /$ hour; $\mathrm{CRP}=24.1 \mathrm{mg} / \mathrm{L})$, antidsDNA antibody level reached $2749 \mathrm{IU} / \mathrm{mL}$ and C3 was $0.58 \mathrm{~g} / \mathrm{L}$. No hypertension or oedema was present.

To confirm LN, she underwent a kidney biopsy, which was consistent with WHO active class IV without significant chronic damage. She was started on MMF $2 \mathrm{~g}$ /day with prednisolone $1 \mathrm{mg} / \mathrm{kg}$ (followed by a decreasing dose until reaching $20 \mathrm{mg}$ /day) and hydroxychloroquine $400 \mathrm{mg} /$ day for 2 months with slight response. She is about to be treated with rituximab cycle as her disease is not yet in remission.

\section{DISCUSSION}

Developing LN more than 15 years after SLE diagnosis is extremely rare and very little is known about this very delayed form of LN. Developing DLN after 34 years of SLE diagnosis is the longest interval reported, as far as we know. ${ }^{9}$ We were unable to find any other single case report or specific case series on this subject. However, we found a few cases included in reported LN cohorts investigated for other reasons with no specific analysis of these patients. ${ }^{510-14}$

We have described three cases of very DLN (table 1). Interestingly, all three were non-Caucasian women. One patient had been diagnosed with SLE during adolescence and the other two during adulthood, but none had lateonset SLE (after 50). The patient reported by Adelman et a $\ell^{\dagger}$ was also a woman with adult-onset SLE but her LN became apparent only when she was 55 years old.

At SLE diagnosis, all three patients had arthritis and two had serositis and rash. Their serological profile shared a high ANA titre with diffuse pattern and anti-dsDNA and anti-Ro antibodies (the latter is known to be an independent risk factor for frequent hospitalisations ${ }^{15}$ ). Despite the previously reported increased risk to develop DLN in patients with SS, ${ }^{16}$ only one of our patients had this. We found a low C3 at SLE onset in just one patient. None of them had antiphospholipid syndrome, which has also been reported to be a risk factor for DLN. ${ }^{16}$

All patients had multiple SLE flares during the course of disease before LN onset. Hydroxychloroquine, known to prevent renal disease and flares in SLE, ${ }^{17}$ was prescribed for most of the disease duration in all patients although we cannot be certain about their compliance. Two of them were treated successfully with rituximab for SLE flares long before LN onset.

The three patients' serum creatinine, eGFR and UPCR were within normal range and there was no detectable proteinuria or haematuria on dipstick from SLE diagnosis until the onset of DLN (these tests were done every time the patients were evaluated at the SLE clinic, 3-4 times a year). Proteinuria and haematuria were present at DLN presentation and two patients developed peripheral oedema and hypertension. The eGFR fell below $70 \mathrm{~mL} /$ $\min / 1.73 \mathrm{~m}^{2}$ in each case. Interestingly, like the patient reported by Adelman $e t a l,{ }^{9}$ our patients also had a WHO class IV LN on biopsy. The biopsies of our patients did not show any chronic component associated with DLN, as opposed to the findings of increased chronicity index found by Xu et al in LLN. ${ }^{7}$ Previous data suggest that high levels of anti-dsDNA are associated with WHO class IV $\mathrm{LN}^{18}$

Importantly, the three patients had serological evidence of increasing disease activity long before $\mathrm{LN}$ was clinically obvious, with rising anti-dsDNA antibody levels accompanying falling C3 values. C3 $<0.65 \mathrm{mg} / \mathrm{dL}$ has been suggested to be a marker of silent $\mathrm{LN},{ }^{19}$ and all our patients were below this threshold from 1 to 3 years before the LN became overt. We acknowledge that silent LN could have been present during this period, becoming clinically evident as the systemic disease went out of control. However, the lack of chronic damage seen in the biopsies after extensive active SLE without LN argues against this 
Lupus Science \& Medicine

\begin{tabular}{|c|c|c|c|}
\hline & Patient A & Patient B & Patient C \\
\hline Age of SLE diagnosis & 28 & 14 & 32 \\
\hline Ethnicity & African & Indian & Asian \\
\hline $\begin{array}{l}\text { Features at SLE diagnos } \\
\text { Cutaneous } \\
\text { Arthritis } \\
\text { Serositis } \\
\text { Neurologic } \\
\text { Haemolytic anaemia } \\
\text { Leucopenia } \\
\text { Thrombocytopenia }\end{array}$ & $\begin{array}{l}+ \\
+ \\
+ \\
- \\
+ \\
- \\
-\end{array}$ & $\begin{array}{l}+ \\
+ \\
+ \\
- \\
- \\
-\end{array}$ & $\begin{array}{l}- \\
+ \\
- \\
- \\
- \\
+ \\
-\end{array}$ \\
\hline $\begin{array}{l}\text { Initial serology } \\
\text { ANA } \\
\text { Pattern } \\
\text { Anti-dsDNA } \\
\text { Anti-Ro } \\
\text { C3 (g/L) } \\
\text { Anticardiolipin } \\
\text { IgM } \\
\text { IgG } \\
\text { DRVVT }\end{array}$ & $\begin{array}{l}>1: 320 \\
\text { Diffuse } \\
+ \\
+ \\
0.69 \\
- \\
- \\
-\end{array}$ & $\begin{array}{l}>1: 320 \\
\text { Speckled+diffuse } \\
+ \\
+ \\
1.21\end{array}$ & $\begin{array}{l}>1: 320 \\
\text { Nucleolar+diffuse } \\
+ \\
+ \\
1.11 \\
- \\
- \\
-\end{array}$ \\
\hline $\begin{array}{l}\text { Progress of SLE } \\
\text { (non-renal) }\end{array}$ & $\begin{array}{l}\text { Multiple arthritis flares (2003- } \\
2010) \\
\text { First trimester miscarriage (2007) } \\
\text { Pleurisy (2009) } \\
\text { Myocarditis (2009) } \\
\text { Renal abscesses (2010) } \\
\text { Pyelonephritis (2010) }\end{array}$ & $\begin{array}{l}\text { Multiple arthritis and rash flares (2006- } \\
2017) \\
\text { Vasculitis in fingers and toes } \\
\text { (2007/2012) } \\
\text { Alopecia (2007) } \\
\text { Dyspnoea, mouth ulcers and headaches } \\
\text { (2008) } \\
\text { Shingles and chest infection (2008) } \\
\text { Acute liver injury secondary to NSAIDs } \\
\text { (costochondritis) (2016) }\end{array}$ & $\begin{array}{l}\text { Multiple arthritis flares (2005-2017) } \\
\text { Discoid lupus (2005) } \\
\text { Raynaud (2008) } \\
\text { Pneumonia (2014) } \\
\text { Pulmonary cysts and calcified nodules } \\
\text { (2015) } \\
\text { Rash (2017) }\end{array}$ \\
\hline
\end{tabular}

Initial renal tests

Serum creatinine $(\mu \mathrm{mol} / \mathrm{L}) \quad 75 \quad 70 \quad 63$

eGFR (mL/min/1.73 $\left.\left.\mathrm{m}^{2}\right) \quad 97\right) 95$

Proteinuria -

Haematuria -

Urinary protein/creatinine ratio $5 \quad-\overline{8} \quad 3$

$(\mathrm{mg} / \mathrm{mmol})$

\begin{tabular}{|c|c|c|c|}
\hline \multicolumn{4}{|l|}{$\begin{array}{l}\text { Features suggesting renal } \\
\text { involvement }\end{array}$} \\
\hline Hypertension & + & + & - \\
\hline Proteinuria & +++ & ++++ & +++ \\
\hline Haematuria & ++ & +++ & ++ \\
\hline Serum creatinine $(\mu \mathrm{mol} / \mathrm{L})$ & 190 & 83 & 89 \\
\hline eGFR $\left(\mathrm{mL} / \mathrm{min} / 1.73 \mathrm{~m}^{2}\right)$ & 30 & 69 & 59 \\
\hline $\begin{array}{l}\text { Urinary protein/creatinine ratio } \\
(\mathrm{mg} / \mathrm{mmol})\end{array}$ & 438 & 986 & 273 \\
\hline Oedemas & + & + & - \\
\hline Biopsy findings & $\begin{array}{l}\text { Very active diffuse proliferative } \\
\text { changes }\end{array}$ & $\begin{array}{l}\text { Patchy background parenchymal } \\
\text { oedema. No chronic damage. } \\
\text { Mix pattern immune complex } \\
\text { glomerulopathy. Endocapillary and } \\
\text { extracapillary active proliferation and } \\
\text { membranous change }\end{array}$ & Very active diffuse proliferative changes \\
\hline WHO LN class & IV & $\mathrm{IV}+\mathrm{V}$ & IV \\
\hline $\begin{array}{l}\text { Time of LN diagnosis in years } \\
\text { after SLE diagnosis }\end{array}$ & 19 & 17 & 15 \\
\hline \multicolumn{4}{|l|}{ Therapeutic for LN } \\
\hline Prednisolone & + & + & + \\
\hline Cyclophosphamide & - & - & - \\
\hline Mycophenolate mofetil & + & + & + \\
\hline Rituximab & - & + & + \\
\hline $\begin{array}{l}\text { Outcome of LN } \\
\text { Duration of follow-up }\end{array}$ & $\begin{array}{l}\text { Partial remission with evolution to } \\
\text { chronic kidney disease } \\
5 \text { years }\end{array}$ & $\begin{array}{l}\text { Complete remission } \\
4 \text { months }\end{array}$ & $\begin{array}{l}\text { Active } \\
2 \text { months }\end{array}$ \\
\hline
\end{tabular}

DRVVT, dilute Russell viper venom time; eGFR, estimated glomerular filtration rate; LN, lupus nephritis; NSAID, non-steroidal anti-inflammatory drug. 
form of long-standing subclinical kidney inflammation. Low complement levels for more than 6 months seem to be an independent risk factor for the development of LN. ${ }^{18}$ This serological pattern antedated any change in urine analysis or kidney function results and may be used in similar patients to raise awareness about the possibility of LN.

Each of the three patients was treated with MMF and steroids, but two needed rituximab to deal with the LN. We used rituximab as an alternative therapy like that suggested by European League Against Rheumatism recommendations for the treatment of refractory $\mathrm{LN} .{ }^{20}$ One patient who had a renal flare after achieving complete remission was managed with MMF but evolved to chronic kidney disease with partial remission. This last patient has a follow-up after biopsy of 5 years, but the others started treatment for LN only 2 and 4 months ago (one achieved complete remission and the other still has active LN). This short follow-up limits further conclusions about outcome.

There is a lack of knowledge about DLN starting more than 15 years after SLE diagnosis. This is explained mainly by its rarity (three patients out of almost 700 in our SLE cohort over 40 years), and also by its delayed presentation confirming the importance of long follow-up of patients with SLE. With the increasing life expectancy of patients with SLE, ${ }^{21}$ it is likely that more cases of very DLN will emerge. The persistent deterioration in C3 and anti-dsDNA antibody levels seen in apparently non-renal patients with very long established disease warrants consideration of the possible onset of kidney involvement. Renal biopsy to search for silent LN or SLE therapy optimisation to prevent renal damage might be reasonable management options.

Acknowledgements The authors thank Dr John Connolly and Dr Ruth Pepper for help in managing the patients.

Contributors The patients have been under the care of DAl who suggested to ARA and PLC that it would be of interest to write them up collectively. The primary writing was undertaken by ARA with subsequent help from PLC and DAI.

Competing interests None declared.

Provenance and peer review Not commissioned; externally peer reviewed. Data sharing statement No additional data are available.

Open Access This is an Open Access article distributed in accordance with the Creative Commons Attribution Non Commercial (CC BY-NC 4.0) license, which permits others to distribute, remix, adapt, build upon this work non-commercially, and license their derivative works on different terms, provided the original work is properly cited and the use is non-commercial. See: http://creativecommons.org/ licenses/by-nc/4.0/

(C) Article author(s) (or their employer(s) unless otherwise stated in the text of the article) 2018. All rights reserved. No commercial use is permitted unless otherwise expressly granted.

\section{REFERENCES}

1. Galindo-Izquierdo M, Rodriguez-Almaraz E, Pego-Reigosa JM, et al. Characterization of patients with lupus nephritis included in a large cohort from the spanish society of rheumatology registry of patients with systemic lupus erythematosus (RELESSER). Medicine 2016;95:e2891-11.

2. Croca SC, Rodrigues T, Isenberg DA. Assessment of a lupus nephritis cohort over a 30-year period. Rheumatology 2011;50:1424-30.

3. Tello B, Jones A, Raine C, et al. Systemic lupus erythematosus: Detailed anatomy of a cohort (follow-up for more than 35 years). Arthritis Rheumatol 2016;68:2283.

4. Imran TF, Yick F, Verma S, et al. Lupus nephritis: an update. Clin Exp Nephrol 2016;20:1-13.

5. Takahashi Y, Mizoue T, Suzuki A, et al. Time of initial appearance of renal symptoms in the course of systemic lupus erythematosus as a prognostic factor for lupus nephritis. Mod Rheumatol 2009;19:293-301.

6. Anaya JM, Cañas C, Mantilla RD, et al. Lupus nephritis in Colombians: contrasts and comparisons with other populations. Clin Rev Allergy Immunol 2011;40:199-207.

7. Xu YX, Tan Y, Yu F, et al. Late onset lupus nephritis in Chinese patients: classified by the 2003 international society of nephrology and renal pathology society system. Lupus 2011;20:801-8.

8. Petri M. Review of classification criteria for systemic lupus erythematosus. Rheum Dis Clin North Am 2005;31:245-54.

9. Adelman DC, Wallace DJ, Klinenberg JR. Thirty-four-year delayedonset lupus nephritis: a case report. Arthritis Rheum 1987;30:479-80.

10. Hui M, Garner R, Rees F, et al. Lupus nephritis: a 15-year multicentre experience in the UK. Lupus 2013;22:328-32.

11. Seligman VA, Lum RF, Olson JL, et al. Demographic differences in the development of lupus nephritis: a retrospective analysis. $A m \mathrm{~J}$ Med 2002;112:726-9.

12. Cortés-Hernández J, Ordi-Ros J, Labrador M, et al. Antihistone and anti-double-stranded deoxyribonucleic acid antibodies are associated with renal disease in systemic lupus erythematosus. Am J Med 2004;116:165-73.

13. Kon T, Yamaji K, Sugimoto K, et al. Investigation of pathological and clinical features of lupus nephritis in 73 autopsied cases with systemic lupus erythematosus. Mod Rheumatol 2010;20:168-77.

14. Wallace DJ, Podell TE, Weiner JM, et al. Lupus nephritis. Experience with 230 patients in a private practice from 1950 to 1980. Am J Med 1982;72:209-20.

15. Lee JW, Park DJ, Kang JH, et al. The rate of and risk factors for frequent hospitalization in systemic lupus erythematosus: results from the Korean lupus network registry. Lupus 2016;25:1412-9.

16. Varela DC, Quintana G, Somers EC, et al. Delayed lupus nephritis. Ann Rheum Dis 2008;67:1044-6.

17. Ruiz-Irastorza G, Ramos-Casals M, Brito-Zeron P, et al. Clinical efficacy and side effects of antimalarials in systemic lupus erythematosus: a systematic review. Ann Rheum Dis 2010;69:20-8.

18. Burling $\mathrm{F}, \mathrm{Ng} \mathrm{J}$, Thein $\mathrm{H}$, et al. Ethnic, clinical and immunological factors in systemic lupus erythematosus and the development of lupus nephritis: results from a multi-ethnic New Zealand cohort. Lupus 2007;16:830-7.

19. Ishizaki J, Saito K, Nawata M, et al. Low complements and high titre of anti-Sm antibody as predictors of histopathologically proven silent lupus nephritis without abnormal urinalysis in patients with systemic lupus erythematosus. Rheumatology 2015;54:405-12.

20. Bertsias GK, Tektonidou M, Amoura Z, et al. Joint European League Against Rheumatism and European Renal AssociationEuropean Dialysis and Transplant Association (EULAR/ERA-EDTA) recommendations for the management of adult and paediatric lupus nephritis. Ann Rheum Dis 2012;71:1771-82.

21. Cervera R, Khamashta MA, Hughes GR. The Euro-lupus project: epidemiology of systemic lupus erythematosus in Europe. Lupus 2009;18:869-74. 